\title{
Tourism \& Hospitality Education in Nigeria: Strategies for Bridging the Issues of Curriculum Gap for Industry Fit and Development
}

\author{
Wasiu A. Babalola, PhD* \\ Tourism \& Hospitality Programme, Department of Management \& Accounting, Faculty of Environment, \\ Management Social Sciences, Lead City University, Ibadan, Nigeria
}

\begin{abstract}
*Corresponding Author: Wasiu A. Babalola, PhD, Tourism \& Hospitality Programme, Department of Management \& Accounting, Faculty of Environment, Management Social Sciences, Lead City University, Ibadan, Nigeria,Email: kikeyemo@yahoo.com
\end{abstract}

\begin{abstract}
The quality and professionalism perception of hospitality/tourism graduates on the important skills needed in the world of hospitality/tourism work and that of hospitality/tourism education is a matter of great debate. Tourism \& Hospitality and tourism students in Nigeria have to consider carefully their career planning in order to comply with the demands of the industry's competitive environment. Although, tourism and hospitality educators have begun to focus on bridging the gap between the acquired knowledge of hospitality graduates and the skills expectations of the industry, few studies have dealt with attributes for the overall employability of graduates from the perspectives of industry managers. Though Curriculum assessment has been an important tool in measuring the effectiveness of the curriculum to evaluate student learning and preparedness, this paper investigates the perceptions of industry managers of employability in the industry. A conceptual framework was developed, based on course offerings and descriptions of the Hospitality and Tourism Management Program at Tertiary Institutions in Nigeria, to evaluate how the curriculum contributes to students' preparedness for their future career. Using an online field survey, it examines the skills that contribute to students' preparedness. Besides the findings indicating that from the perspectives of industry managers, both students and graduates lack confidence in their employability, particularly in areas of professional management skills, it revealed that communication skill, multi-lingual, operational skills and skills in computing are the most prominent skills that are needed to fit into the industry. However, graduates are unable to deliver owing to inadequate possession of the generic skills which impede their performance in the industry. There are also no evidence of government interventions to drive educationindustry research collaboration for the tourism and hospitality and tourism industry, despite its undoubted importance to the Nigerian economy. Suggestions are provided for facilitating the employability of hospitality graduates in Nigeria while addressing the 'low skills' economy which tourism and hospitality represents. It draws upon the work of Noon \& Blyton (1995) in applying their approach to the classification and analysis of skills within tourism and hospitality and also draws on Ashton \& Green's (1996) critique of vocational education as a basis for understanding some of the problems inherent in skills development in tourism and hospitality. Finally, it addresses the skills debate in tourism and hospitality in four key theme areas: the nature of work and skills in tourism and hospitality; de-skilling within the tourism and hospitality and tourism workplace; the technical/generic skills debate within tourism and hospitality; skills and the education/training process in tourism and hospitality. It is highly recommended however that, there should be a close collaboration between the educators and the industry players so that students leave school knowing industry expectation.
\end{abstract}

Keywords: hospitality and tourism education, work experience, benefits, challenges, career plans, industry expectations, tourism \& hospitality and tourism education, tourism \& hospitality gap analysis

\section{INTRODUCTION}

The hospitality and tourism industry is also one of the most diversified industries in the world because of the wide number of different occupations and professions involved in it. The industry also operates on regional, national, as well as global levels and involves different sectors of an economy such as government, non-profit, and for profit. The hospitality and tourism industry is one of the largest industries in the world. About $90 \%$ of US workforce is employed in the service sectors of which many are part of the various sectors of the hospitality and tourism industry. Millions of jobs, with billions of 
dollars in economic contributions are generated either directly or indirectly by the hospitality and tourism industry in the United States alone, which benefits large segments of society, as well as the federal, state, and local governments (Goeldner \& Ritchie, 2009). In Nigeria, Travel \& Tourism generated US\$7.6 trillion (10.2\% of global GDP) and 292 million jobs in 2016, equivalent to 1 in 10 jobs in the global economy. The sector accounted for $6.6 \%$ of total global exports and almost $30 \%$ of total global service exports. The Hospitality/Tourism Industry in Nigeria contributed about $4.8 \%$ to Nigeria's Gross Domestic Product in 2016. The industry also employed about $1.6 \%$ of Nigerians same period. In terms of travel contributions to the country's GDP, foreign spending accounted for $3 \%$ while domestic spending took the bulk of $97 \%$.

The role of skills and skills development through training in the contemporary economy is a matter of considerable academic and political debate. With turnaround of the 21 st century, the focus on the service industry has been drawn dramatically. Several factors can be accounted for the increasing emphasis on the service industry such as new technology enhancements, customers diverse needs, more choices available for customers, and skyrocketing competitions among companies. In view of this, many studies have also stressed on the important skills needed by the hospitality students in order for them to be part of the hospitality industry. For example, Connolly and McGing (2006) suggested that hospitality curriculum and courses must consist of strong practical skills and 'soft' people management skills. Furthermore, researchers such as (Goodman\& Sprague, 1991, Kang, Wu, \& Gould, 2005, Petrova and Mason, 2004 and Ladkin, 2005 as cited in Goh, 2011 have also criticized tourism and hospitality educators for not adequately preparing students for employment in the industry. They often claim that, what educators teach in the classroom does not match current industry trends. This sometimes impedes employment opportunities for hospitality / tourism graduates (Dale and Robinson, 2001; Airey, 2005, Asirifi et al.., 2013).

As an applied discipline, hospitality and tourism education has a close and strong linkage with its industry in order to educate hospitality and tourism students by keeping abreast with the current industry trends (Goodman \& Sprague, 1991). However, a shortage of skilled and specialized labour has been an ongoing issue in the hospitality and tourism industry. A growing demand of hospitality and tourism workers and a shortage of skilled and specialized labour can be translated into a growing demand of hospitality and tourism educational programs to adequately prepare the workforce to meet present and future demands in this enormous industry. Reigel (1995) defines hospitality and tourism education as a multidisciplinary field, which brings the perspectives of many disciplines, especially those found in social sciences to bear on particular areas of application and practice in the hospitality and tourism industry.

The diverse field requirements have given rise to different types of specialized programs through which students learn their multidisciplinary skills in order to succeed in this industry. Hospitality and tourism programs across the world can be uniquely administered based on where they are housed. Many Hospitality and tourism programs are housed on business, management and social science, agriculture, food science, human ecology, or consumer science. The programs are also quite different in the type of concentration areas they offer. As a result of these complications, it is very challenging to come up with a consistent curriculum assessment and program ranking in this field, which is very much evident in the existing hospitality and tourism literature. Hospitality and tourism education has been a widely studied area and so is hospitality and tourism curriculum assessment. The hospitality and tourism industry is a service oriented area; most of the hospitality and tourism programs put more weight on industry expectations and opinions. As a result, most of the relevant hospitality curriculum studies tend to focus on the employer's perspective, with very few focusing on the actual providers and recipients of the education. Often employers (i.e. industry practitioners) lack the adequate knowledge to rationally assess hospitality curricula. Students and faculty members, on the other hand, can rationally assess the hospitality and tourism programs in regards to how well they contribute to students' preparedness for their future hospitality career as students are participating in learning as part of the curriculum and the faculty in delivering education to the student and in developing the curricula to some extent. It is often stressed that some level of industry involvement is important in hospitality curriculum assessment as the hospitality and tourism education is heavily linked to the industry. 
To understand the dynamics of hospitality and tourism education, it is important to have a simplistic, yet, detailed viewpoint of the hospitality and tourism industry. Several research works have defined and categorized the industry. Table 1 shows a simplistic breakdown of the hospitality industry.

Table1: The structure of the hospitality and tourism industry

\begin{tabular}{|l|l|l|l|}
\hline $\begin{array}{l}\text { Free-Standing } \\
\text { Hospitality Business }\end{array}$ & $\begin{array}{l}\text { Hospitality in Leisure } \\
\text { Venues }\end{array}$ & $\begin{array}{l}\text { Hospitality in Travel } \\
\text { Venues }\end{array}$ & Subsidized Hospitality \\
\hline Hotels & Casinos & Airports & Workplaces \\
\hline Holiday Centers & Bingo Clubs & Rail Stations & Health care \\
\hline Quasi Hotels & Night Clubs & Bus Stations & Education \\
\hline Cruise Ships & Cinemas & Ferry Terminals & Military \\
\hline Time-share & Theatres & Aeroplanes & Custodial \\
\hline Bars & Sports Stadia & Trains & Retailers \\
\hline Restaurants & Theme Parks & Ferrie & \\
\hline & Attractions & & \\
\hline & Health Clubs & & \\
\hline
\end{tabular}

(Source: Slattery, P. (2002) Finding the Hospitality and tourism industry. Journal of Hospitality, Leisure, Sport and Tourism Education).

The world is now a global village and this generational change is also taking place in Nigeria. Most highly rated and branded hotels in Nigeria are having non-hospitality major at the helm of affair. Consequently, the government parastatals are also not headed by core tourism professionals. Presently the front office department of the hotel is no go area for hospitality and tourism major, as it is now exclusive preserve of graduates of Social Sciences and Humanities. Hospitality and tourism graduates have to beat down the doors to rise through a company because of the entrenched nature of the accountancy and legal world (Gude, 1997). While graduates in the hospitality related disciplines are now left with Food and Beverage department, graduates of Food technology, Marketing, Accounting and other disciplines that so wish to work are also employed at the food and beverage department.

This paper draws upon both these diversity environments in order to consider issues in relation to skills in hospitality and tourism. It draws upon the work of Noon \& Blyton (1995) in applying their approach to the classification and analysis of skills within hospitality. Their approach is to consider skills in terms of personal attributes, job requirements and the setting of work. This classification raises questions about a number of the widely unquestioned assumptions pertaining to hospitality and tourism work that are evident in the literature. It also draws on Ashton \& Green's (1996) critique of vocational education as a basis for understanding some of the problems inherent in skills development in hospitality. In addressing the strategies for bridging the issues of curriculum gap for industry fit and development, the following issues were discussed:

- Nigeria tourism and hospitality education landscape and Curriculum Assessments

- Skills debate in hospitality and tourism

- Student Industrial Work Experience

- Perception of Key Industry Players

\section{THEORETICAL FRAMEWORK}

The framework used in this study consists of skills or competencies developed from hospitality and tourism courses and a few generic competencies taken from past research. The framework that has been established for the purpose of this study uses both generic skills/competencies and hospitality specific ones. The broad categories of skill sets consist of generic skills and hospitality related skills such as fundamental skills, functional area skills, and students' concentration area skills. In order to develop these skills (except the generic skills), the courses have been analyzed thoroughly by looking at the course descriptions. Then, these courses were grouped according to functional and concentration areas. Functional areas, broadly categorized from the curriculum, consist of marketing, human resource, finance, facilities and systems, and information technology. The concentration areas are categorized by those offered by the Hospitality undergraduate program such as food and beverage, clubs, lodging, casino, events, and tourism and travel. The courses offered under these categories are analyzed and key skills, knowledge and competencies are developed as curriculum variables. Some 
general learning techniques from the curriculum such as experimental learning and application, experience based learning and application, understanding current issues and practices in the hospitality and tourism industry are categorized under fundamental curriculum related skills. Based on these identified skill sets and variables, the following conceptual framework has been developed (Baum, 2002): Figure 1 indicates a detailed overview of these categories, courses, variables, and descriptions of our proposed framework:

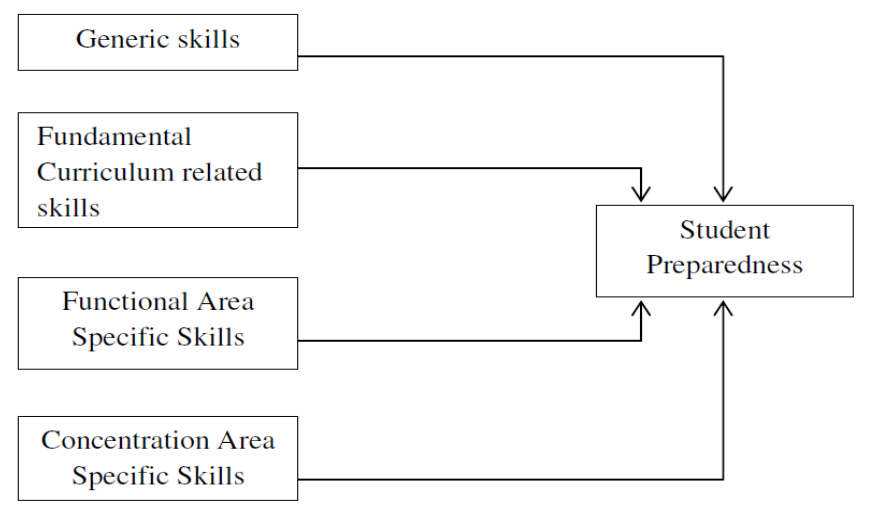

Figure1: A framework for measuring students' preparedness

Generic skills in the study's framework consist mainly of the skill sets recognized by past research as part of the literature review. The breakdown of the generic skills is shown in Figure 2.

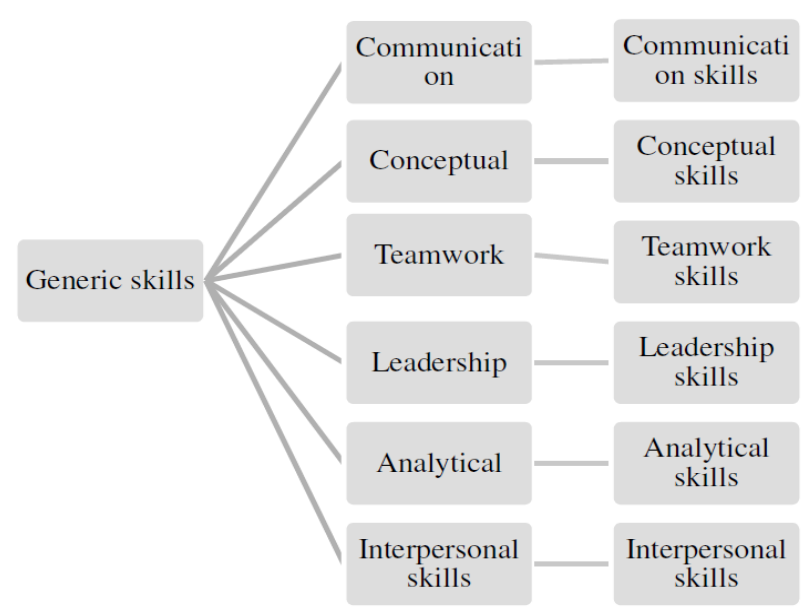

Figure2: Key elements that belong to generic skills

Fundamental curriculum related skills have been divided into three variables based on the analysis of the courses offered in the curriculum. These are shown in Figure 3.

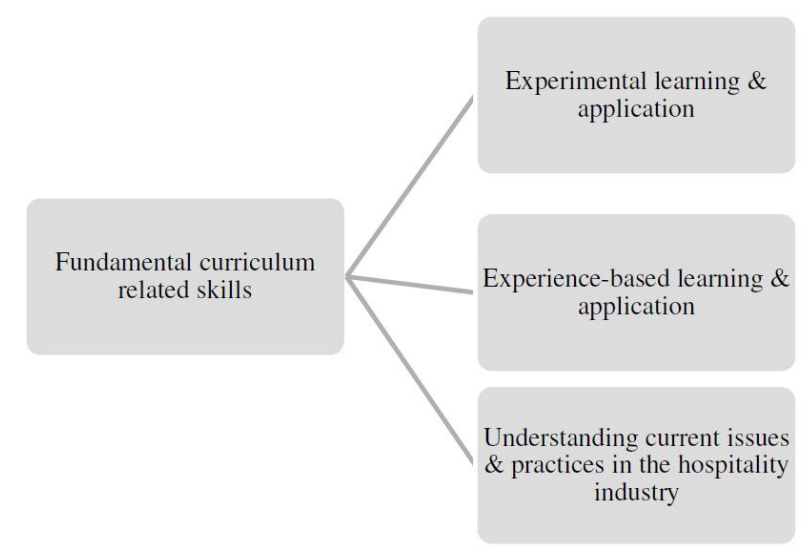

Figure3: Key elements that belong to fundamental curriculum related skills 
As mentioned above, functional area specific skills are broken down into five broad skill sets from the analysis of the courses offered in the curriculum. These five broad areas are further broken down into a number of curriculum variables based on the analysis of the courses offered in the curriculum. The breakdown of functional area is illustrated in Figure 4.

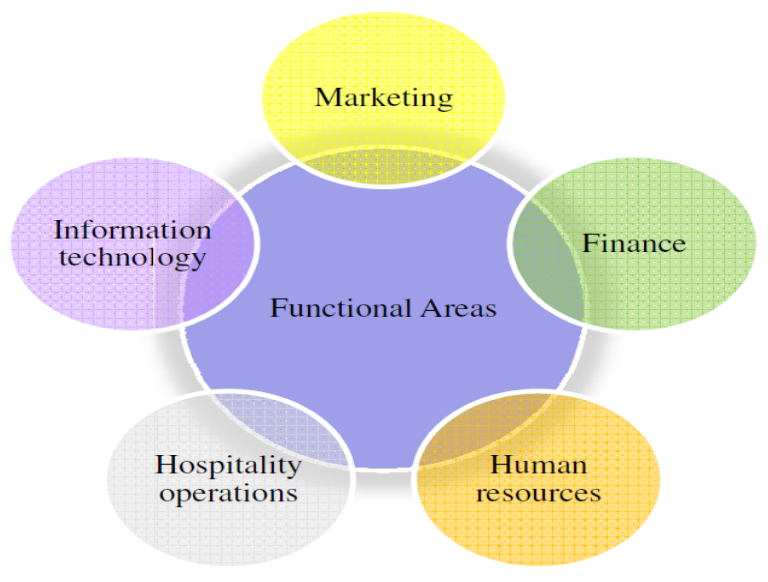

Figure4: Breakdown of functional area

Similarly, concentration area specific skills are broken down into six broad areas from the analysis of the courses offered in the curriculum. These five broad areas are further broken down into a number of curriculum variables based on the analysis of the courses offered in the curriculum. Their breakdown is illustrated in Figure 5.

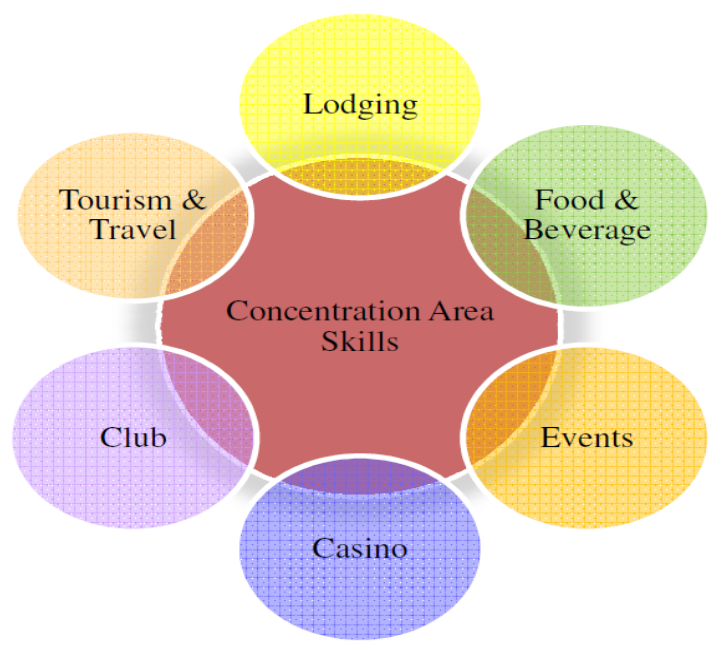

Figure5: Breakdown of concentration area

Analysing the Nigerian tertiary institution curriculum reflects a partly generic, fundamental and concentration skills as shown in the table below:

Table2: Analysis of Nigeria University and polytechnic's hospitality and tourism curriculum

\begin{tabular}{|l|l|l|l|l|}
\hline & & \multicolumn{2}{|c|}{ Polytechnic } & \multicolumn{1}{|c|}{ University } \\
\hline & & National Diploma (ND) & Higher National Diploma (HND) & Bachelor (BSc) \\
\hline 1 & Concentration / Core & $71.25 \%$ & $58.44 \%$ & $42.94 \%$ \\
\hline 2 & Functional / Business & $11.25 \%$ & $23.38 \%$ & $44.63 \%$ \\
\hline 3 & Others & $17.5 \%$ & $18.18 \%$ & $12.43 \%$ \\
\hline & & $100 \%$ & $100 \%$ & $100 \%$ \\
\hline
\end{tabular}

In most profession the core courses always has the highest credit unit $(\mathrm{CU})$, but this is not the case in the Hospitality and Tourism program as offered by the Universities. How would one explain a situation where from the total credit unit for a B.Sc. in Hospitality and Tourism Management of which core business related courses has $44.63 \%$ yet the graduates find it difficult to reach the pinnacle of their profession. 


\section{NigERIA TOURISM AND HOSPITALITY EDUCATION LANDSCAPE AND CURRICULUM ASSESSMENTS}

The Nigerian higher education curricula are regulated by the National University Commission, established in 1962, who is in charge of the Universities and the National Board for Technical Education, which was established by Act No. 9 of 11th January 1977 to handle all aspects of Technical and vocational education outside the university education. The wide array of hospitality fields has contributed immensely to the growth of hospitality and tourism education. According to Iyiade (2011) Out of one hundred and six (106) universities in the country, only sixteen (16) universities are offering hospitality and tourism related courses. These universities are newly established and are either State or privately owned. Only one Federal university is running the program with only twenty six (26) polytechnics offering this program (JAMB Brochure 2011). As at 2017, this had improved to twenty one (21) universities offering 21 bachelor's programme, 5 Masters programme and 3 doctoral programmes; and forty (40) programmes/courses offered by thirty two (32) polytechnics. Majority of these post graduate degrees are tourism biased. It was further observed that Hospitality and Tourism education in the universities in Nigeria is in confusion as to which faculty the program should be run 10 of the universities has it attached under the faculty of administration, 8 has it under faculty of Agriculture and the remaining 3 universities placed it under faculty of social science and management studies (JAMB Brochure 2017). Compared to the United State as reported by Rappole in the early 1970s, there were about 27 bachelor's programs, 7 Master's and 2 doctoral programs in the 4-year institutions in the United States (Kent, et al., 1993). However, since 1992, the number of each degree has dramatically changed: 142 bachelor's programs, 26 Master's programs, and 12 doctoral programs (CHRIE, 1991).

Various subjects are covered as part of hospitality and tourism education such as finance, management, marketing, accounting, and information systems, which ultimately help hospitality and tourism students prepare for their future career to fit in each of the specialized fields in the hospitality and tourism industry. With more and more 2-year or 4-year institutions opting in for hospitality and tourism education, assessing the hospitality curriculum has become a key issue as far as preparing a student for a successful career in the hospitality and tourism industry in Nigeria.

In Nigeria, hospitality/ tourism tertiary education faces great challenges in the development of human capital for the hospitality/ tourism industry. Even though the main purpose of the hospitality and tourism programme is to equip students with knowledge and skills to meet industry needs, graduates are not able to articulate their skills in which they have been trained to work. Asirifietal.., (2013) and Avornyo(2013).

\section{SKILlS DEBATE IN HOSPITALITY AND TOURISM}

Interpretation of the nature of hospitality and tourism work is predominantly a social construct and we are more interested in how work in the sector is perceived than in what the actual operational tasks involve. On the face of it, there is little about hospitality and tourism work and the skills it requires that is unique to the sector. There is, however, a studied argument [see, for example, Lashley \& Morrison, 2000, as well as Seymour's (2000) discussion of emotional labour] that it is the context and combination of these skills that does generate unique attributes. Therefore, the debate about skills issues, in the context of hospitality and tourism, is informed by wider, generic consideration about skills in the context of changing employment, technology and vocational education, within both developed and developing economies.

Hospitality and tourism work (and thus the skills that it requires for its delivery) exhibits diversity in both horizontal and vertical terms. Horizontal diversity reflects the breadth of the sector from fast food outlets and bed and breakfast establishments to elite resorts, and 'style' hotels and clubs. Vertical diversity is reflected in the range of technical, service and managerial tasks that are undertaken 'under the one roof'.

The paper addresses the skills debate in hospitality and tourism in four key theme areas:

- The nature of work and skills in hospitality;

- De-skilling within the hospitality and tourism workplace; 
- The technical/generic skills debate within hospitality;

- Skills and the education/training process in hospitality.

\subsection{The Nature of Work and Skills in Hospitality}

The traditional research focus on hospitality work concentrates on areas that provide, primarily, food and beverage (Mars \& Nicod, 1984; Gabriel, 1988) and, to a lesser extent, accommodation. Coverage of this discussion is well served by reference to Wood (1997), Guerrier \& Deery (1998) and others. Hospitality and tourism work (and thus the skills that it demands) exhibits diversity in both horizontal and vertical terms. In a horizontal sense, it includes a very wide range of jobs, the extent depending upon the definition of the sector that is employed. Research into wider areas of hospitality and tourism work, particularly those that have emerged with the expansion of services and functions in the area (front desk, leisure, entertainment, reservations call centres) is much more poorly served and this study draws on a limited range of work in these areas. The 'newer' areas include functions and tasks that exhibit considerable cross-over with work that falls out with normal definitions of hospitality in food and drink manufacture, office administration, IT systems management and specialist areas of sports and leisure. Indeed, it is fair to say that although there is long-standing debate as to whether the hospitality and tourism industry is unique' (Mullins, 1981; Lashley \& Morrison, 2000), there is little doubt that there is little that is unique about hospitality skills. Most of the skills that are employed within the sector also have relevance and application in other sectors of the economy. Those employed in areas where there is considerable skills overlap with hospitality and tourism, such as the areas listed above, may well see themselves in terms of their generic skills area, rather than as part of the hospitality labour market. Some of these skills have been subject to separate assessment (Ecotec, 2001) in a manner that has value and cross-over implications for the hospitality sector. The characteristics and the organisation of the hospitality and tourism industry are subject to on-going restructuring and evolutionary change. There are major labour market and skills implications of such change as businesses re-shape the range of services they offer (Hjalager \& Baum, 1998), or respond to fashion and trend imperatives in the consumer marketplace (Warhurst et al, 2000).

Vertical diversity in hospitality and tourism work is represented by a more traditional classification that ranges from unskilled to semi-skilled, and from skilled to supervisory and management. This 'traditional' perspective of work and, therefore, skills in hospitality is partly described by Riley (1996) in terms that suggest that the proportionate breakdown of the workforce in hospitality is as follows:

Managerial $-6 \%$

Supervisory $-8 \%$

Craft (skilled) $-22 \%$

Operative (semi skilled and unskilled) $-64 \%$

This simplification masks major business organisational diversity in hospitality, reflecting the size, location and ownership of hospitality businesses. The actual job and skills content of work in hospitality is predicated upon these factors so that common job titles (e.g. restaurant manager, sous chef) almost certainly mask a very different range of responsibilities, tasks and skills within jobs in different establishments. The skills profile of hospitality, in turn, is influenced by the labour market that is available to it, both in direct terms, and via educational and training establishments. The weak internal labour market characteristics in themselves impose downward pressures on the skills expectations that employers have of their staff and this, in turn, influences the nature and level of training that the educational system delivers. There is an evident cycle of down-skilling, not so much in response to the actual demands of hospitality and tourism work or of consumer expectations of what it can deliver, but as a result of the perceptions of potential employees and the expectations that employers have of them.

Hospitality and tourism work is widely characterised in both the popular press and in research-based academic sources as dominated by a low skills profile (Wood, 1997) or, as Shaw \& Williams (1994), rather brutally and, probably, unfairly put it, 'uneducated, unmotivated, untrained, unskilled and unproductive'. However, Burns (1997) questions the basis for categorising hospitality employment into 'skilled' and 'unskilled' categories, arguing the post-modernist case that this separation is 
something of a social construct. This construct is rooted in, first, manpower planning paradigms for the manufacturing sector and, secondly, in the traditional power of trade unions to control entry into the workplace through lengthy apprenticeships. Social and inter-personal skills also demand considerably more by way of prior learning, whether this pertains to language skills (English is a widespread prerequisite for hospitality and tourism work in countries such as Nigeria) or wider cultural communications.

It is also useful, in summary of this section of the debate, to consider hospitality and tourism work in the light of the work of Noon \& Blyton (1995). Their approach is to consider skills in terms of personal attributes, job requirements and the setting of work. This approach, with a focus on the context of work, both from an individual and organisational point of view, is much more sympathetic to the realities of diversity within hospitality work. Noon and Blyton (1995) appear to accept that what is skilled work in one context may be less so in another, influenced by both the cultural context of the work, and also by the availability and application of technology. It is argued, therefore, that a simple labelling of hospitality and tourism work as 'unskilled' is both unhelpful and unjustifiable.

\subsection{De-Skilling within the Hospitality and Tourism Workplace}

The extensive debate that surrounds the issue of 'McDonaldisation' as introduced to the literature by Ritzer (1993) and developed by Leidener (1993), Lyon et al (1994) and others, has suggested that deskilling is an inevitable consequence of growing standardisation or routinisation across the service sector. There is evidence to support this process in hospitality and tourism in the form of a growing fast food sector; within budget accommodation, and through the growth of no-frills airlines (Baum, 1997; Pender \& Baum, 2001). The growth of these sectors all point to a simplification of tasks in the workplace, aided in part by technology substitution, but also by changes in consumer demands and expectations. It is also arguable that these sectors have grown in response to new consumer demand as opposed to displacement of demand for traditional services. Therefore, while their growth may have had the global effect of 'dumbing down' average skills levels in hospitality and tourism; it is difficult to argue that they have eliminated demand for higher order skills within other sectors of the industry.

Parsons \& Marshall (1995) summarise the arguments of a number of studies about changes in skills across various industry sectors. Their analysis of research from the mid-1980s onwards shows:

$>$ Traditional skills and functional boundaries breaking down in many occupations, leading not to functional fragmentation, but to multi-skilling in more integrated tasks;

$>$ The effect on skills not easy to predict, due to different management strategies on task reorganisation;

$>$ Relatively little de-skilling, disproportionately concentrated on lower skill and craft-level jobs where barriers to cross-trade reskilling had reduced the potential for integration;

$>$ Much inter-occupational hybridisation of skills at all occupational levels and in manufacturing and service sectors, combined with both up-skilling and de-skilling;

$>$ Demand for higher-level occupations stimulated by the effect of structural trends and labour supply on employers' interpretation of skill needs.

This analysis has relevance in the context of changing skills in hospitality. The argument that hospitality is moving towards increasingly multi-skilled models of training and work has been aired since the early 1980s (Baum, 1987). The focus of this argument has been targeted towards meeting employer needs, particularly in smaller businesses where the notion of flexible rotation between different hotel departments in a way to suit the demand cycle is presented as a logical business solution. In reality, such work represents multi-tasking because the level and nature of the work in question (food service, bar service, portering, housekeeping) offers little by way of enhancing the actual skills of employees other than extending the operational context within which they are exercised (Baum, 1995).

\subsection{The Technical/Generic Skills Debate within Hospitality}

Historically, skills in hospitality were seen almost exclusively in terms of their technical requirements, and this formed the basis of the training agenda pursued by colleges in Europe and, subsequently, in the developing world through funded aid programmes, for much of the twentieth century. Jobs in 
hospitality, likewise, were constructed on the basis of an accumulation of skills required for specific technical tasks [International Labour Organization (ILO), 1979]. Changes in the nature of work, the impact of technology and customer expectations have forced a fundamental re-evaluation of the relative roles of technical and generic skills in hospitality and tourism work.

Skills shortages in hospitality are increasingly seen in terms of generic rather than specific technical competencies. Studies of employer expectations of graduates (Tas, 1988; Baum, 1990; Christou, 1997, 2000) note demand for communications, people management and problem solving, as the priority in both the US and Europe. It is, of course, an issue that informs a debate across the service sector. However, Hospitality Training Foundation (HtF, 2000a) continues to report employer demands for improved generic skills as a priority. These skills include communications, showing initiative, delivering customer service and demonstrating a willingness to learn. Recommendations to tackle the generic skills gap include:

- Building generic skills development into full-time education programmes;

- Funding for training providers to deliver key skills and develop appropriate aptitudes and attitudes within young people;

- Ensuring providers are developed to be able to deliver key skills;

- Recruitment practices need to encompass generic skills requirements.

HTF's (2000b) delphi study of skills requirements in hospitality also reports that the skills gaps, as seen by the hospitality and tourism industry, focus on what can be styled the generic agenda communications, problem solving and customer service in addition to job specific skills. Empirical evidence from a study of front office work and skills requirements across a number of European countries (Baum \& Odgers, 2001; Odgers \& Baum, 2001) shows clearly that this focus operates in practice. Hotels in all quality categories in seven European countries recruit on the basis of generic employability rather than specific skills and experience. Odgers \& Baum (2001) note that even 5-star hotels 'accept the reality of the marketplace and are willing to recruit staff without Front Office experience provided they have good general education and a willingness to learn'. The same report also notes that: A key evolving change in Front Office work is the integration of technical and interpersonal skills in all aspects of work. This is the result of a growing emphasis on the latter while technology has developed as a support for the delivery of service rather than as an objective in itself. In a technical sense, technology will continue to reduce the skills demands of Front Office work as systems become more users friendly and share their basic operating features with widely used office and domestic computer software. The weakening of traditional workplace hierarchies in front office, with a decline in the position of junior or assistant receptionist so that given 'the virtual elimination of traditional, routine office-related tasks such as basic typing, filing and photocopying, it is, in any case, difficult to distinguish between the job content' of various levels of work within the area. Indeed, ongoing studies in Glasgow suggest that recruitment criteria employed within the hospitality sector increasingly recognise the triangular nature of skills - technical, generic and aesthetic. The priority accorded to each of these depends on the nature of the job and the type of business that is involved.

HTF's skills and employment forecasts (HTF, 2000c) raise an interesting paradox in the hospitality skills debate. Employers, as has been demonstrated, place value on generic skills, such as the willingness to learn and the ability to be flexible and adaptive. At the same time, initiative is also a valued skill and one found to be lacking in the industry. HTF raise two important questions:

- Are employers being unrealistic in their expectations? People who are good at following instructions may not be able to show much initiative.

- Are employers recruiting the 'right' people? If, when recruiting, employers focus on people they feel are good at following instructions, they may find later that they cannot expect them to show much initiative.

These questions are of particular relevance in the context of trends towards and advocacy for greater empowerment in learning and work (Foresight, 2000). 


\subsection{Skills and the Education/Training Process in Hospitality}

Education and training for hospitality has developed, historically, over a period in excess of 100 years with the burden of investment, in most countries, shared between the public sector (schools, colleges, universities, and training boards) and private enterprises. The traditional focus was on the development of technical skills in core hospitality areas, and this remains the rationale and priority within programmes in many countries. Recognition of the need to complement technical with generic skills has emerged over the past two decades and is well represented in subject benchmarks for the sector in the United Kingdom Quality Assurance Agency (QAA, 2000). However, if the argument that hospitality and tourism work is essentially low skills in nature is sustained, questions must be raised about the level of public investment in skills development targeted at the sector over the past 100 years. This analysis would draw upon Ashton \& Green's (1996) critique of the economic benefits of vocational education. However, if the nature of hospitality skills is recognised as rather more contextual in nature, such investment may be justified although the predominantly technical nature of much of its delivery may not.

The development of skills to meet the needs of various stakeholders in hospitality and tourism is frequently seen as a partnership between the industry and the educational/training providers, with each playing a complementary role. The extent of their respective involvement depends upon the objectives and level of training as well as upon the system in which such training is located. Guerra \& Peroni (1991) note a relatively homogeneous hospitality and tourism industry in Europe, but point to considerable diversity within the educational and training systems that operate alongside the industry, reflecting differences in national vocational education systems, as well as diversity in the status and focus of tourism and hospitality at a national or regional level. This diversity is clearly reflected in the structure of hospitality skills programmes in different European countries. Also in Nigeria, university and polytechnic students are expected to have some level of industrial exposure often referred to as SIWES or IT prior to completion or advancement of studies, although, this often provides limited formal and assessed exposure of the students to the industry during the programme.

Higher-level education and training for hospitality and tourism generally maintains a clear commitment to the development of skills designed to complement more generic educational and business development objectives. Busby (2001) analyses the content of tourism degrees in the United Kingdom and concludes that what he describes as vocationalism is a strong feature in provision. Such vocationalism includes the development of specific skills in hospitality and travel-related areas, and, Busby argues, these elements play an important role in ensuring the employability of graduates. Within hospitality, a key skills issue that is bound up in the traditions of the sector, particularly in Europe, is the significance of food and beverage skills development as a necessary stepping stone towards the application of general management skills within hotels. Ladkin's (2000) study of the careers of hotel managers confirms the widely held perception that food and beverage experience remains the single dominant career characteristic of successful general managers, although the revenue contribution of this area is relatively less important than that of accommodation (Horwarth \& Horwath, 1999). Ladkin (2000) notes that few successful general managers have significant training or experience in rooms, accounting and marketing functions prior to their entry into general management. This suggests a continuing focus on traditional food and beverage skills development within the educational process despite the stated expectations of employers. In Nigeria however, the focus is more on employees with business backgrounds than that of food and beverages or other technical backgrounds such as rooms. This is a complex issue and there is relatively little evidence to suggest that 'industry needs' are represented by a single perspective. Indeed, given the diversity within the industry, it is unlikely that unanimity could ever be achieved with respect to the training and education that is required.

The case for integrated skills planning and development in hospitality and tourism is widely argued in the literature (for example, Amoah \& Baum, 1997; Baum et al, 1997). Keep \& Mayhew (1999) questioned where responsibility for such integration of skills development lies. In the Irish case and elsewhere (Esichaikul \& Baum, 1998), it is clearly seen as that of the state, but this is clearly not the only option. Traditional models of education and training for hospitality place considerable responsibility for skills development and the consolidation of learning on vocational work experience or internship. 
The value of working experience as part of a platform for skills development towards job finding and career development is widely accepted. Employers need to get more involved in work placement schemes and they should be thinking long term about the future of recruitment. At the moment there are not enough employers involved and the schemes are not always comprehensive enough.

\section{STUDENT INDUSTRIAL WORK EXPERIENCE}

Students can benefit from experiences outside the academic classroom. Generally this is done through employment at an industrial establishment (work experience) or through internship (cooperative education) opportunities. This section examines the work experiences of hospitality and tourism students, and student internships to better identify benefits and challenges, as well as current practices.

\subsection{Hospitality and Tourism Students' Work Experiences}

Kozar, Horton, and Gregoire (2005) surveyed a class of hospitality and tourism students to determine if working at a job while enrolled in classes had positive or negative effects on class attendance, hours spent studying, and participation in social activities. Students recorded their daily activities for a fourweek period following class discussions on time management. One class of 58 students participated in the study; the response rate was $91 \%(N=53)$. On average, students in the study worked less than 12 hours per school week while taking a full course-load (15 credits per semester for all but 2 students). Utilizing ANOVA, the authors examined the correlation between student variables including grades, attendance, study time, and work time. Kozar et al. (2005) reported no statistically significant differences among the variables; however when students' work hours increased, their study time and time spent attending classes decreased.

Barron (2007) examined part-time employment of Australian hospitality and tourism undergraduates to document their work habits and impressions of part-time work experiences. A questionnaire sent to the undergraduate students yielded 486 usable responses (response rate of 94.0\%); 372 (77.0\%) of the students had part-time jobs. The students attended classes 12 hours per week and worked an average of 16 hours per week; $16.0 \%$ worked less than 10 hours and $15.0 \%$ worked more than 26 hours (Barron, 2007). Barron found students reported negative aspects of part-time work experiences were dealing with difficult customers, completing boring job tasks, and interacting with supervisors; $67.2 \%$ reported that working did not detract from their studies.

Martin and McCabe (2007) explored UK postgraduate students' part-time work habits to determine how their work influenced future employment. A survey distributed to hospitality and tourism postgraduate programs throughout the country yielded a response rate of $9.0 \%(N=95)$; responses were received from eight graduate programs. Sixty-two percent of the respondents held part-time jobs while taking classes full-time, and $86.0 \%$ believed their part-time work experiences contributed to their applicable skills (e.g. team-work, adaptability, communication and problem-solving). Students working part-time studied more hours per week than those not working; $41.0 \%$ of unemployed students studied less than ten hours per week while $13.0 \%$ of those working part-time studied less than ten hours per week (Martin \& McCabe, 2007).

\subsection{Internship Experiences}

Dickerson and Kline (2008) conducted a study to determine the benefits a cooperative experience has on hospitality and tourism students' early career retention by comparing three programs that offer a combination of academic credit and include classroom components. A mail-based survey was sent to recent alumni from three Hospitality and tourism programs having their own variation of a cooperative experience for students, with a $33 \%$ overall response rate $(N=155)$. The three programs are described below; they show differences in the amount of credit given and the inclusion of classroom components:

- Program A combined at least 600 hours of work experience with a minimum of six academic credits.

- Program B required a minimum of 600 hours of work but did not include classroom components concurrently, though academic coursework was required separately and credit was awarded for experience. 
- Program C required a minimum of 600 hours of work experience, yet had no classroom components and did not offer academic credit for experience.

All three programs (A, B, and C) showed high percentages of graduates who entered the hospitality and tourism industry directly after graduation $(93.5 \%, 87.0 \%$, and $90.3 \%$, respectively). However, participants' tenure in the industry showed statistically significant differences $(76.6 \%, 76.1 \%$, and $64.5 \%$, respectively). Although most Hospitality and tourism programs required some type of cooperative experience, the experiences varied greatly. At the same time, industry professionals were pushing students to gain additional industry-based experiences (Dickerson \& Kline, 2008).

Molseed, Alsup, and Voyles (2003) explored the involvement level and perceptions held by business owners toward providing student workers successful learning experiences. In a survey of Black Hills, SD businesses, a response rate of 62.7\% $(N=64)$ was achieved, including 13 businesses representing the hospitality and retail industries specifically; most respondents were from health care $(n=15)$. Overall, the survey respondents rated on a five-point Likert-type scale $(1=$ strongly disagree, to $5=$ strongly agree) commitment $(M=4.41)$, personal responsibility $(M=4.40)$, and problem-solving skills $(M=4.21)$ as the highest skills necessary, and collaboration $(M=3.91)$, decision-making skills $(M=$ 3.82) and career development $(M=3.72)$ as the least necessary skills (Molseed, Alsup, \& Voyles, 2003). Results of the study showed participating employers believed they had a role to play in students' work experience; however, experience specifics varied across the industry segments represented.

Rothman (2007) surveyed post-intern students at a UK business school. He was interested in what students thought about their intern experiences, and what suggestions they might give supervisors to improve future students' experiences. Rothman utilized a three question survey (open-ended) asking students how their employers could improve the internship experience, and distributed the surveys inclass to business-school students following their semester internship experience (response rate 85.8\%) $(N=345)$. Ten percent suggested the experience could be enhanced if students were provided more specific information at the internship sites, including orientations, expectations, and training (Rothman, 2007). Rothman suggested that although the internship experience's value is not in question, especially with $28.0 \%$ of students $(n=97)$ deeming the experience positive even when asked to make suggestions for improvement, the majority still offered valuable suggestions for better academic institution and employer collaboration to improve the experience for all students. The literature shows that work experience provides benefits and challenges for both hospitality and tourism students. Understanding stakeholders' perceptions and ideals can contribute to the value of particular work or internship experiences.

\section{Perceptions of Key Stakeholders}

Stakeholders' ideas often vary dramatically, and when they do, potential issues and challenges can affect all parties. When it involves hospitality and tourism students' knowledge and skill development, employment problems can be created if the students' perceptions and ideas differ from those of the managers and industry. This section examines perceptions and ideas of both students and industry managers, and addresses key factors involved in education, learning and the industry.

\subsection{Student Perceptions}

Richardson (2008) examined career attitudes and perceptions in the hospitality and tourism industry among Australian undergraduate students majoring in hospitality. Questionnaires were adapted from Kusluvan and Kusluvan (2000) who focused on similar research questions in a study conducted in Central Europe. The author narrowed the scope of the study to include students who had current or previous work experience; $73.3 \%(N=63)$ of the original sample completed the web-based questionnaires. Student responses indicated $43.6 \%$ were unlikely to work, or would not work in industry following graduation; $96.3 \%$ of those students cited previous experience as their primary reason (Richardson, 2008). Of the students without work experience, all stated they planned to work in industry following graduation. Challenges seen throughout the hospitality and tourism industry were highlighted, including compensation, promotion opportunities, manager relationships, and work conditions. 
Richardson (2010) examined the thoughts and concerns of Generation Y students beginning a career in the hospitality and tourism industry. Undergraduate students were surveyed in leading Australian universities to garner their thoughts and ideas about career choice after working within the hospitality and tourism industry. The response rate was $25.3 \%(N=379) ; 66.0 \%$ of respondents were female and $57.5 \%$ were first-year students. An industry-person congeniality test was administrated and showed that $74 \%$ of students surveyed enjoyed working within the industry. Richardson (2010a) reported student concerns, including lack of relationships between managers and staff $(60.7 \%)$, career opportunities based on who one knows rather than ability (54.1\%), and low pay for work performed (57.7\%). Richardson reported the vast majority of Generation Y students stated the industry was interesting (85.5\%) and they would be able to learn new things (75.1\%); however, half of the total sample had already planned to leave the industry citing stress as the major factor, and $58.3 \%$ of those students were contemplating careers outside the hospitality and tourism industry.

Lu and Adler (2009) examined career goals and future career expectations of undergraduate hospitality and tourism students from four Chinese universities. A four-part questionnaire was developed that included the following sections: educational preparation, industry expectations, personal expectations, and demographics. The response rate was $86.7 \%(N 24=503)$. Only $16.1 \%$ of students chose the hospitality and tourism major as their first choice, while $64.6 \%$ of students reported they did not choose the major; hospitality and tourism was assigned to them by the university based on low test scores. Over two-thirds of the students stated they planned to pursue an advanced degree following graduation. $\mathrm{Lu}$ and Adler reported less than one-third of the respondents declared they would not work in industry following graduation, citing a lack of personal interest and unsuitable personality type as the major reasons for their decision (Lu \& Adler, 2009). According to Lu and Adler, holding powerful jobs and making money were the students' most important goals. Such ideals can be challenging for the hospitality and tourism industry, where a significant period of time is typically spent in entry-level positions early in ones' career.

\subsection{Industry Perceptions}

Tesone and Ricci (2005) surveyed current hospitality lodging managers to determine the knowledge, skills, and abilities entry-level hospitality employees should possess. The sample consisted of managers who were members of a Central Florida lodging association; the survey yielded a $97.5 \%$ response rate $(N=156)$. The majority $(87.9 \%)$ indicated that because of their current job satisfaction, they would recommend hospitality jobs to a person close to them. Managers were asked to indicate their preference for new employee attributes on a five-point Likert-type scale $(1=$ poor, to $5=$ excellent). The highest rated attributes were knowledge of grooming and professional standards $(M=$ $4.43)$, ability to work as a team $(M=4.57)$ and pride in satisfying customers $(M=4.31)$ (Tesone \& Ricci, 2005). Lodging managers overall believed the most successful competencies for entry-level managers were teamwork, communication skills, and customer service.

Countryman and Horton (2006) examined qualities club managers seek when hiring entry-level supervisors. Participants were asked to view six prepared resumes (from hypothetical job applicants) and answer questions based on the resume case study; a $15.0 \%$ response rate $(N=133)$ came from club managers registered by the Club Managers Association of America. Managers rated resumes four $(72.1 \%)$ and five $(71.0 \%)$ as preferred because each hypothetical applicant held a Bachelor of Science degree in Hotel and Restaurant Management, rather than another business entity, and had obtained an above average GPA (grade point average) (Countryman \& Horton, 2006). Leadership skills acquired in an earlier job, or as a student, were also shown to be in high demand by managers.

Ricci (2010) examined ideas, opinions, and expectations held by current lodging managers toward new hires. An online survey focusing on general managers' ideas about new hires from both hospitality management and non-hospitality management undergraduate programs, and was sent to 500 hotel general managers listed as members of the American Hotel \& Lodging Association. A response rate of 63.4\% $(N=317)$ was achieved. Respondents expected more from hospitality graduates than nonhospitality graduates on a five-point Likerttype scale $(1=$ strongly disagree, to $5=$ strongly agree $)$ in various knowledge-based areas, including realities of work (4.42 for hospitality graduates compared to 3.49 for non-hospitality graduates), lodging management practices (4.26 compared to 3.01), and products and services (4.28 compared to 2.97) (Ricci, 2010). Ricci (2010) reported expectations for 
students are held to a higher standard for hospitality program graduates when compared to general business program graduates, although the lodging concepts taught in each school's hospitality program varies.

Fjelstul (2007) explored the competencies needed by golf and club entry-level management professionals. A web-based questionnaire was distributed to members of the Florida Club Managers Association of America and yielded an overall response rate of $14.0 \%(N=87)$. Fjelstul stated that entry-level core competencies reported by managers were strong skills and knowledge in beverage management (94.3\%), cost control (94.3\%), leadership (85.1\%), and financial accounting (81.6\%). The knowledge, abilities and attitudes entry-level managers needed were also assessed. The most frequently identified competencies in each category were business management and ethics, anticipating guests' wants and needs, and personal pride in satisfying the needs of others (Fjelstul, 2007). In consideration of recruitment, prospective employees were encouraged to gain specific experience to enhance their academic competence in their chosen industry segment.

Alonso and O'Neill (2011) explored characteristics defining an ideal hospitality employee. Obtaining business entrepreneurs' opinions, they identified a number of challenges concerning the business respondents. Interviews were conducted with small and medium-sized business owners and managers located within a college town, with a response rate of $51.2 \%(N=21)$. Respondents were asked to identify desired employee characteristics when hiring; the top attributes included punctuality (38.1\%), being good with people (23.8\%), and dependability/responsibility (19.0\%) (Alonso \& O'Neill, 2011). Alonso and O'Neill discussed the respondents' many challenges finding good quality help, regardless of the college environment; generally, this included a lack of basic skills, poor attitude, and work ethic.

Raybould and Wilkins (2005) examined hospitality managers' expectations of graduate skills compared to those of students. A questionnaire presented 52 hospitality related skill descriptors for respondents to rank. A total of 371 managers (43.6\% response rate) and 211 undergraduate students were included in the study. Some skills were ranked higher by students than managers. Those with the largest gaps in rankings included (student ranking and management ranking): time management ( 2 and 7), communication with peers (4 and 9), motivating and encouraging employees (5 and 11), safety and sanitation (6 and 14), and delegation of responsibility (14 and 27) (Raybould \& Wilkins, 2005). Gaps existed between managers' expectations and students' perceptions when identifying specific skills desirable in graduates.

\subsection{Education and Learning}

Hospitality and tourism programs must provide students with rigorous academic courses while also exposing them to numerous practical learning opportunities; such a balanced educational experience will prepare today's students to be tomorrow's managers. Often Hospitality and tourism programs offer unique course offerings and experiences for students. A few recent studies have examined similarities and differences among programs and are presented below. Additionally, perceptions and ideas of industry (managers), and those of educational institutions (administrators and professors) are examined.

Muller, VanLeeuwen, Mandabach, and Harrington (2009) examined Eastern Canadian culinary graduates' skill attainment by comparing current students, recent graduates, and industry representatives. The overall response rate was $65.8 \%$ with group response rates as follows: current students at $67.2 \%(n=84)$, recent graduates at $70.0 \%(n=112)$ and industry professionals at $51.6 \%(n$ $=31$ ). Each group could access a separate online survey. The majority of respondents from all three groups were satisfied with technical skills $(88.1 \%, 91.1 \%$, and $93.5 \%$, respectively); satisfaction with teamwork skills for both students and recent graduates was more than $89.0 \%$. However for industry professionals, only $71.0 \%$ were satisfied with the students' abilities (Muller, VanLeeuwen, Mandabach, \& Harrington, 2009). Muller et al. reported satisfaction with communications skills (via computer, speaking, and writing) was relatively low for both graduated students $(47.7 \%, 38.4 \%$, and $34.2 \%$, respectfully) and current students $(19.3 \%, 19.0 \%$, and $26.5 \%$, respectfully). Although technical skills are required for hospitality positions, communication skills are also needed for industry success; students may not be achieving an adequate level of these critical skills in their academic programs. 
Blake and Worsdale (2009) examined the impact students' part-time work had on their academic success, and if skills obtained during these experiences would qualify for academic credit. A questionnaire was distributed to approximately 1,715 full-time UK business school students, and 342 questionnaires (20\% response rate) were returned. The surveyed students worked part-time, mainly in hospitality $21.9 \%$ (bars, restaurants, and hotels), supermarkets $21.1 \%$, and retail stores $21.1 \%$. The top six skills utilized during part-time work experiences were team-work $(85.3 \%)$, customer care $(78.4 \%)$, communications $(77.1 \%)$, cash handling (66.2\%), problem solving (47.6\%), and sales $(44.2 \%)$. The findings showed part-time work increased students' knowledge and skills, and developed both their personal and social competencies within the business setting, which should be a welcomed addition to a business school's curriculum (Blake \& Worsdale, 2009).

\subsection{Education and Industry}

Millar, Mao, and Moreo (2011) examined both hospitality and tourism educators' and industry professionals' views and perceptions about competencies taught in undergraduate programs in the United States. Twenty educators and professionals (9 representing food and beverage and 11 representing lodging) completed the study, which combined in-depth interviews and a panel discussion. The food and beverage representatives (educators and industry professionals) agreed on needed competencies. However, gaps in agreement were found between the lodging representatives, most notably in the areas of communications, customer service, and understanding of general operations (Millar, Mao, \& Moreo, 2011).

Leiper, Hobson, and Lewis (2007) explored individual differences among professionals in the hospitality and tourism industry to help resolve misunderstandings between academic and industry professionals. The authors' direct observations and previous experiences were utilized in this study. The authors noted six domains where differences occurred: first industry position held, theories and practices (as related to primary work responsibilities), questioning and doubting (as related to job functions), research, primary responsibilities, and education and training. Educators and industry professionals, though different, work broadly in conjunction with each other in the same industry; they may not be in direct cooperation, however they need to realize their differences and together support their shared ideals and values (Leiper, Hobson, and Lewis, 2007).

\section{RECOMMENDATIONS AND CONCLUSION}

It emerged from the study that communication skill, multi lingual, operational skills and skills in computing as the most prominent skills that are needed by the students to fit into the industry. However, graduates are unable to deliver owing to inadequate possession of the generic skills and hence impeded their performance in the industry. Consequently, there should be a close collaboration between the educators and the industries.

The manpower being supplied by the colleges and the universities offering hospitality and tourism programme in the country are not totally relevant in the scheme of things in the industry. The polytechnics (colleges) and universities are emphasizing basic and craftsmanship, as the backbone of the profession, base on the curriculum being used in the polytechnic while the hospitality and tourism operators are emphasising more on managerial capability. This is the main reason why people from core business program are made to head the hotel, thus a gap exit between the hospitality and tourism program curriculum as being executed presently in the polytechnic and universities and the need of the hotel operators (Iyiade, 2011). It is a fact that the hotel is in need of those who can cook, serve food, clean rooms but all those staff operates within the lower strata in the hotel organisation. A ceiling is placed on them as to which position they can hold within the hotel. This is where the bulk of National diploma (ND) and Higher National Diploma (HND) in hospitality and tourism management and even Bachelor of Science (BSc.) holders falls within this crop of employees.

The gap in industry's expectations and colleges' delivery would have been adequately addressed had industry experiences been a prime requirement for jobs in the hospitality and tourism academic in Nigeria as in advanced world. In that aspect, the educators will be in a better position to evaluate because they can interpret both sides of the coin: the academics and the industry. Thus, addressing education and industry skill gaps in hospitality and tourism education should involve both the 
perspectives of the learners, and the knowledge providers who are experts in both industry and academia.

Furthermore, there should be an extension period of internship for university students. University students on internship should spend about 6 months instead of current twelve weeks and there should be a way for the students to rotate in different sections in order for them to acquire skills in all areas of the department. This is evidence in that their counterpart in the polytechnic often spend about 15 months before completion of programme and are observed to be often preferred in the industry, although, there may be need for further research on this.

There is the need for hospitality and tourism management faculties / lecturers with first qualification in hospitality and tourism management to leverage their positioning by obtaining post graduate qualification in property/project management, personnel management, financial management, marketing, management, food service, food production, beverage management etc but this is not the case in this country. This will make graduates to be widely accepted both in the hotel and other business concern like merchandising, sales and marketing, consultancy, e.t.c.. There is the need for profession rebirth (repositioning) of the Hospitality and Tourism Management program in Nigeria for it to be acceptable and relevant both in the Hospitality industry and merchandising business. However, faculty members can also lack specific knowledge about the curriculum outside their teaching emphasis, and thus might not be accurate judges of student preparedness outside their area of expertise. Moreover, their level of judgment of student preparedness from their own area can be highly biased because they are the ones who are delivering the learning to the students.

It is recommended that tertiary institutions should strengthen the study of communications skill in both written and orally. This is because communication skills are needed in every important aspect of managerial activity such as, recruiting, defend and argue a case convincingly, make a business presentation, conduct staff briefing interview, training, orientation, interacting with guests and writing effective business memo, letters, e-mails, reports and many other managerial responsibilities that require communications skills.

\section{REFERENCES}

[1] Airey, D., \& Tribe, J. (2005) Issues for the future. In: D. Airey, \& J. Tribe (Eds.), An international handbook of tourism education (pp. 501-506). UK: Elsevier

[2] Alonso, A. D., \& O'Neill, M. A. (2011). What defines the "ideal" hospitality employee? A college town case. International Journal of Hospitality \& Tourism Administration, 12, 73-93.

[3] Amoah, V.A. \& Baum, T. (1997) Tourism Education: policy versus practice, International Journal of Contemporary Hospitality Management, 9, pp. 5-12.

[4] Ashton, T. \& Green, F (1996) Education, Training and the Global Economy. Cheltenham: Edward Elgar.

[5] Asirifi, G. H., Doku, V., Morrison, S. \& Sackey, A. S. (2013). The Gap between the Hospitality Education and Hospitality Industry. Journal of Education and Practice. Vol.4, No.24, 2013

[6] Avornyo, R. (2013). Bridging the gap between the tourism industry and tertiary institutions offering tourism in Ghana: a case study of Cape Coast. European Scientific Journal December 2013 /SPECIAL/ edition vol.2

[7] Barron, P. (2007). Hospitality and tourism students' part-time employment: Patterns, benefits and recognition. Journal of Hospitality, Leisure, Sport, \& Tourism Education, 6, 40-54.

[8] Baum, T. (1987) Introducing Educational Innovation in Hospitality Studies: a case study in practical curriculum change, International Journal of Hospitality Management, 6, pp. 97-102.

[9] Baum, T. (1990) Competencies for Hotel Management: industry expectations of education, International Journal of Contemporary Hospitality Management, 2/4, pp. 62-70.

[10] Baum, T. (1995) Human Resource Management in the European Tourism and Hospitality Industry. London: Chapman and Hall.

[11] Baum (2002): Skills and training for the hospitality sector: a review of issues, Journal of Vocational Education \& Training, 54:3, 343-364

[12] Blake, J., \& Worsdale, G. J. (2009). Incorporating the learning derived from part-time employment into undergraduate programmes: Experiences from a business school. Journal of Further and Higher Education, $33,91-204$.

[13] Baum, T. (1995) Human Resource Management in the European Tourism and Hospitality Industry. London: Chapman and Hall. 
[14] Baum, T. (1996) Unskilled Work and the Hospitality Industry: myth or reality? International Journal of Hospitality Management, 15, pp. 207-210.

[15] Baum, T. (1997) No Frills but Sound Business Sense: a look at economy-sector trends in travel and tourism, Insights, December.

[16] Baum, T. and Odgers, P. (2001) Nerve Centre or Nerd Centre - the Changing Role of Front Office in the Contemporary Hotel Sector, paper to CHME Research Conference, South Bank University.

[17] Busby, G. (2001) Vocationalism in Higher Level Tourism Courses: the British perspective, Journal of Further and Higher Education, 25, pp. 29-43.

[18] Christou, E. (1997) Hospitality Management Competencies for Graduate Trainees: the view of employment, Journal of European Business Education, 7, pp. 28-40.

[19] Connolly, P. \&McGing, G. (2006). Graduate Education and Hospitality Management in Ireland. International Journal of Contemporary Hospitality Management, 18(1), 50-59.

[20] Countryman, C. C., \& Horton, B. W. (2006). Qualities and characteristics club managers look for in entry level supervisors. Journal of Human Resources in Hospitality \& Tourism, 7, 47- 62.

[21] Dale, C., \& Robinson, N. (2001). The theming of tourism education: a three-domain approach. International Journal of Contemporary Hospitality Management, 13 (1), 30-34.

[22] Dantata, M (2008) Regulating Hotel Franchise in the Nigeria's Hospitality Industry. Term paper presented to Dept. of Tourism and hospitality Management. Faculty of Management and Ent. Studies. Lead City University Ibadan.

[23] Dickerson, J. P., \& Kline, S. F. (2008). The early career impact of the co-op commitment in hospitality curricula. Journal of Teaching in Travel \& Tourism, 8(1), 3-22.

[24] Ecotec (2001) Sector Skills Study: food and drink manufacturing, a final report to Wiltshire and Swindon Training and Enterprise Council. Birmingham: Ecotec.

[25] Esichaikul, R. \& Baum, T. (1998) The Case for Government Involvement in Human Resource Development: a study of the Thai hotel industry, Tourism Management, 19, pp. 359-370.

[26] Fjelstul, J. (2007). Competencies and opportunities for entry level gold and club management careers: Perceptions from the industry. Journal of Hospitality \& Tourism Education, 19(3), 32-38.

[27] Foresight (2000) The Learning Process in 2020 Task Force. Point and Click: learners in the ICT driving seat. London: Foresight/ DTI.

[28] Gabriel, Y. (1988) Working Lives in Catering. London: Routledge

[29] Goeldner \& Ritchie, 2009

[30] Goh, E. (2011). The value and benefits of fieldtrips in Tourism and Hospitality education.Higher learning communication. Volume 1, (1).

[31] Gude, M. (1997) Response to article" Are we heading for mediocrity" written by Slattery, P. and Teare, R. in the august 1997 issue of Hospitality. Hospitality. Official Journal of Hotel, Catering and International Management Association, September/October 1997.

[32] Guerra, D. \& Peroni, G. (1991) Occupations within the Hotel Tourist Sector within the European Community. Berlin: CEDEFOP.

[33] Guerrier, Y. \& Deery, M. (1998) Research in Hospitality Human Resource Management and Organizational Behaviour, International Journal of Hospitality Management, 17, pp. 145-160.

[34] Hjalager, A-M. \& Baum, T. (1998) Upgrading Human Resources: an analysis of the number, quality and qualifications of employees required in the tourism sector, paper for the High Level Working Group on Tourism and Employment. Brussels: Commission of the European Union.

[35] Horwath \& Horwath (1999) Worldwide Industry Study. London: Horwath and Horwath.

[36] Hospitality Training Foundation (2000a) Hospitality Sector Workforce Development Plan 2001. London: HtF.

[37] Imo State University, Owerri, School of Business Studies; Course Content and Descriptions; Hospitality and Tourism Management: Curriculum

[38] International Labour Organization (1979) Tasks to Jobs - Developing a Modular System of Training for Hotel Occupations. Geneva: ILO.

[39] Iyiade A. (2011) Redefining The Nigerian Education Framework Of Hospitality, Leisure And Tourism Courses For Efficiency And Industrial Relevance, A Paper delivered at the Institute of Hospitality, UK 2nd Business Conference, Ikoyi, Lagos, Nigeria

[40] JAMB Brochure (2017) available online www.jamb.org.ng/. $8^{\text {th }}$ November 2017, 15.55

[41] Keep, E. \& Mayhew, K. (1999) Skills Task Force Research Group. Paper 6. The Leisure Sector. London: DfEE. 
[42] Kozar, J. M., Horton, B. W., \& Gregoire, M. B. (2005). Is gaining work experience while going to school helping or hindering hospitality management students? Journal of Human Resources in Hospitality \& Tourism, 4(1), 1-10.

[43] Ladkin, A. (2000) Vocational Education and Food and Beverage Experience: issues for career development, International Journal of Contemporary Hospitality Management, 12(4), pp. 207-218.

[44] Lashley, C. \& Morrison, A. (Eds) (2000) In Search of Hospitality. Oxford: Butterworth-Heinemann.

[45] Leidener, R. (1993) Fast Food, Fats Talk: service work and the routinisation of everyday life. Berkeley: University of California Press.

[46] Leiper, N., Hobson, J. S. P., \& Lewis, P. (2007). Shall we dance? A step towards resolving the misunderstandings between hospitality and tourism academics and industry practitioners. Journal of Hospitality \& Tourism Education, 19(4), 45-51.

[47] Lu, T., \& Adler, H. (2009). Career goals and expectations of hospitality and tourism students in China. Journal of Teaching in Travel \& Tourism, 9(1/2), 63-80.

[48] Lyon, P., Taylor, S. and Smith, S. (1994) McDonaldization: a reply to Ritzer's thesis, International Journal of Hospitality Management, 13, pp. 95-100.

[49] Martin, E., \& McCabe, S. (2007). Part-time work and postgraduate students: Developing the skills for employment? Journal of Hospitality, Leisure, Sport \& Tourism Education, 6, 29-40.

[50] Mars, G. \& Nicod, M. (1984) The World of Waiters. London: Allen and Unwin.

[51] Millar, M., Mao, Z., \& Moreo, P. (2011) Hospitality \& tourism educators vs. the industry: A competency assessment. Journal of Hospitality \& Tourism Education, 22(2), 38-50.

[52] Molseed, T. R., Alsup, J., \& Voyles, J. (2003). The role of the employer in shaping students' work-related skills. Journal of Employment Counselling, 40, 161-171.

[53] Muller, K. F., VanLeeuwen, D., Mandabach, K., \& Harrington, R. (2009). The effectiveness of the culinary curricula: A case study. International Journal of Contemporary Hospitality Management, 21(2), 167-178.

[54] Mullins, L.J. (1981) Is Hospitality Unique? Hospitality, September, pp. 30-33.

[55] Noon, M. \& Blyton, P. (1995) The Realities of Work. Basingstoke: Macmillan.

[56] Odgers, P. \& Baum, T. (2001) Benchmarking of Best Practice in Hotel Front Office. Dublin: CERT.

[57] Parsons, D. \& Marshall, V. (1995) Skills, Qualifications and Utilisation. A Research Review. London: Department for Education and Employment.

[58] Pender, L. \& Baum, T. (2000) Have the Frills Really Left the Airline Industy? International Journal of Tourism Research, 2/6, pp. 423-436.

[59] Raybould, M., \& Wilkins, H. (2005). Over qualified and under experienced. International Journal of Contemporary Hospitality Management, 17, 203-216.

[60] Reigel C. D. (1995) An introduction to career opportunities in hospitality and tourism. A guide to programmes in Hospitality and Tourism (4th ed.). New York: John Wiley \& Sons, Inc.

[61] Ricci, P. (2010). Do lodging managers expect more from hospitality graduates? A comparison of job competency expectations. Journal of Human Resources in Hospitality \& Tourism, 9, 218-232.

[62] Richardson, S. (2008). Undergraduate tourism and hospitality and tourism students attitudes toward a career in the industry: A preliminary investigation. Journal of Teaching in Travel \& Tourism, 8(1), 23-46.

[63] Richardson, S. (2010). Generation Y's perceptions and attitudes towards a career in tourism and hospitality. Journal of Human Resources in Hospitality \& Tourism, 9, 179-199.

[64] Riley (1996) Human Resource Management in the Hospitality and Tourism Industry, 2nd edn. Oxford: Butterworth-Heinemann.

[65] Ritzer, G. (1993) The McDonaldization of Society. Thousand Oaks: Pine Forge Press.

[66] Rothman, M. (2007). Lessons learned: advice to employers form interns. Journal of Education for Business, 82(3), 140-144.

[67] Seymour, D. (2000) Emotional Labour: a comparison between fast food and traditional service work, International Journal of Hospitality Management, 19, pp. 159-171.

[68] Shaw, G. \& Williams, A. (1994) Critical Issues in Tourism: a geographical perspective. Oxford: Blackwell.

[69] Slattery, P. (2002), finding the hospitality industry, Journal of Hospitality, Leisure, Sport and Tourism management. 1(1) 19-28

[70] Tas, R.E. (1988) Teaching Future Managers, Cornell Hotel and Restaurant Administration Quarterly, 29(2), pp. 41-43. 
[71] Tesone, D. V., \& Ricci, P. (2005). Job competency expectations for hospitality and tourism employees: Perceptions of educational preparation. Journal of Human Resources in Hospitality \& Tourism, 4(2), 53-64.

[72] University of Ado-Ekiti, Ado Ekiti, Faculty of the Social and Management Sciences, External Degree programme: Masters in Business Administration: Curriculum.

[73] Warhurst, C., Nickson, D., Witz, A. \& Cullen, A.M. (2000) Aesthetic Labour in Interactive Service Work: some case study evidence from the 'new Glasgow', Service Industries Journal, 20(3), pp. 1-18.

[74] Wood, R.C. (1997) Working in Hotels and Catering, 2nd edn. London: Routledge

Citation: Wasiu A. Babalola. "Tourism \& Hospitality Education in Nigeria: Strategies for Bridging the Issues of Curriculum Gap for Industry Fit and Development". International Journal of Research in Tourism and Hospitality (IJRTH), vol 5, no. 3, 2019, pp. 07-25. doi: http://dx.doi.org/10.20431/2455-0043.0503002.

Copyright: (C) 2019 Authors. This is an open-access article distributed under the terms of the Creative Commons Attribution License, which permits unrestricted use, distribution, and reproduction in any medium, provided the original author and source are credited. 